\title{
Development of Ngoc Linh ginseng in Nam Tra My district
}

\author{
Viet Hanh $\mathrm{Ho}^{1, *}$, and Quoc Tri Pham ${ }^{2}$ \\ ${ }^{1}$ Graduate Academy of Social Science, 477 Nguyen Trai Street, Hanoi, 10000, Vietnam \\ ${ }^{2}$ Institute of Social Sciences of the central Region, Vietnam Academy of Social Sciences, Nam Ky \\ Khoi Nghia street, Danang city, 550000, Vietnam
}

\begin{abstract}
Ngoc Linh Ginseng is a medicinal plant with high economic value and has been selected by the Prime Minister of Vietnam as a national brand product. Ngoc Linh ginseng development has helped a lot of households in Nam Tra My mountainous district, Quang Nam, Vietnam escape from poverty and become billionaires in just 4 years. The article explains that success through research and analysis of stakeholders' roles from central and local governments to business organizations and people in the conservation and development of Ngoc Linh ginseng. The article also implies suggestions for the development of other agricultural products.
\end{abstract}

\section{Introduction}

Nam Tra My is a mountainous district, located in the southwest of Quang Nam province, Vietnam, about $100 \mathrm{~km}$ from the provincial capital to the southwest. The district has a total natural area of 82,253 ha; with population of 28,260 people/6,692 households, and is home to the people of Cadong, Xe Dang, Bh'nong, Kinh and other ethnic groups. Ethnic minorities in the district alternately live together, with a tradition of "clinging" to the forest to unite and help each other. In terms of geographical location, the average height of the district is about $1000-1500 \mathrm{~m}$ above sea level, with regular rainfall in months and mostly concentrated from October to December each year. The intensity of air illumination is abundant, the soil is fertile, the topsoil of the forest is less eroded; therefore, it is convenient for plants to grow and develop well, especially for medicinal plants. At present, medicinal plants in Nam Tra My district are very diverse such as: Tra My cinnamon, codonopsis pilosula, ginseng, jiaogulan, anoectochilus setaceus, crataegus cuneara, true cardamom, etc. Especially Ngoc Linh ginseng is grown by people in the communes of Nam Tra My district, contributing significantly to hunger eradication and poverty reduction quickly and sustainably.

According to the research of Ministry of Health of Vietnam (1978), while North Korean ginseng has only about 25 saponins, the rhizome of Ngoc Linh ginseng contains 26 saponin compounds with known chemical structure and 24 compounds with new structure which are not included in other ginseng types. In the latest isolating chemical composition research, the list of saponins in Ngoc Linh ginseng is even extended with a total of 52

\footnotetext{
*Corresponding author: hanhcjs@yahoo.com
} 
types. Therefore, Vietnam ginseng is one of the ginsengs with the highest saponin content, similar to some of the precious ginseng plants that have been studied and used for a long time worldwide. Diverse chemical compounds and practical effects on human health make Ngoc Linh ginseng's price increase, many times higher than North Korean ginseng.

According to the research from Vietnam Institute of Medicinal Materials (2011), Ngoc Linh ginseng have demonstrated the effects against physical, psychological stress and depression, stimulating the immune system, being antioxydant, protecting liver cells, increasing energy level, restoring impairment to help the body's condition back to normal, promoting anti-aging effects. It also resists to toxins that cause cell damage, helps extend the cell life, increases new cells, stimulates the regulation of immune mechanisms, increases the body's resistance, prevents and fights against cancers. The special effect of Ngoc Linh ginseng is antibacterial, anti-psychological effect that North Korean and Chinese ginseng cannot reflect. Clinical pharmacological research of Ngoc Linh ginseng also shows good results: patients eat well, sleep well, gain weight, increase eyesight, improve mental and physical activities, increase resistance, improve the cases of neurasthenia and genital depression, raising blood pressure in people with low blood pressure.

As one of the two localities that receives geographical indications for Ngoc Linh ginseng from Intellectual Property Department - Ministry of Science and Technology of Vietnam, Quang Nam province is taking firm steps to preserve and develop ginseng with national branding. Currently, Quang Nam province has planned the development areas in seven communes of Nam Tra My district with a total area of 19,000 ha including: the buffer zone area of over 6,000 ha, the core area of nearly 9,000 ha. From 2016 to 2020, the planted and preserved area is estimated at 665.4 ha (People's Committee of Quang Nam Province, 2016).

After the certificate of geographical indications was recognized, the value of Ngoc Linh ginseng also increased highly, the price of a 1-year-old ginseng seed grows from 50,000 VND to 250,000 - 300,000 VND per tree; ginseng price on average is from 50-75 million/kg; the special 200-gram ginseng tube ranges from 150-200 million VND/kg. Every hectare of growing ginseng can earn 30 to 50 billion VND after 5 years. The high economic value of ginseng has impacted on people's awareness dramatically, the farmers know how to keep the forest, take advantage of the land under the canopy of the ginseng plantation to increase income and improve their qualities of life. Nam Tra My has exited the top 62 poorest districts of Vietnam, with the poor household rate of more than $82 \%$ (2014) decreased to 37.37\% and no near-poor households (2019) (Nam Tra My District People's Committee, 2020a). Thousands of households escaped from poverty and hundreds of them has become billionaires within 3-4 years. Ngoc Linh ginseng has been identified as the key plant for poverty reduction in the district, helping to improve social security for people in Nam Tra My district, Ca Dong and Xe Dang people. It also has helped hundreds of people get out of poverty and improve their life, making people become billionaire (Nguyen Viet Thien, Nguyen Tai Phuc, 2016). Ngoc Linh ginseng is considered a special product, with potential to grow into national brand, having more medical value than North Korean, Chinese and American ginseng and with high economic value. Therefore, the orientation of Ngoc Linh ginseng development is associated with forest protection, being the basis for hunger eradication and poverty reduction, raising livelihoods and building new rural areas for highlanders of Nam Tra My district, Quang Nam Province.

To accomplish this task, the role of authorities from the central to local levels, from businesses to people is very important in the conservation and development of this precious ginseng. It is crucial to determine the importance and source preservation of Ngoc Linh ginseng to develop its material area, limit deforestation and natural environment damage, increase economic development and poverty reduction. In 2015, the Prime Minister of 
Vietnam agreed to implement the project "Conservation and Development of Ngoc Linh ginseng until 2030" to protect precious genetic resources, protect the forest, eradicate hunger and reduce poverty in areas with difficult socio-economic conditions in Quang Nam province. After more than four years of implementation, there has been different socioeconomic results from investment attraction to various infrastructure improvements. It has proved the roles of authorities, businesses and people in reducing poverty and improving livelihoods for people in Nam Tra My district.

\section{Theoretical framework and hypotheses}

According to the study of Kuotsai Tom Liou (2007), the state plays a very important role in the economic system. The government's economic policies are considered successful if they can address five key roles: (1) promoting growth, (2) identifying the role in managing the economy, (3) distributing and sharing income for economic system entities, (4) having mechanisms to manage the production activities and (5) protecting citizens and businesses, helping them jointly develop and benefit from the policies.

Fu-Lai Yu, T. (2000) also concludes that the state has specific roles in regulating economic parties in competition, cooperation and exchange level depending on the state policies' purpose. The study found that government support for dynamic private enterprises and individual business households helped post-war Japanese economy and other developing economies in Asian developing countries have recovery and rapid growth.

Research by Amrita Dhaliwal (2016) shows that the role of enterprises is not the same in different economic sectors. Depending on natural conditions, physical resources, business environment and responsiveness of the political system, the role of businesses varies in each economic sector. The contribution of businesses can increase the value of products, complement the supply chain in the market and bring benefits to the community. At the same time, it can increase pressure in the industry environment, grow fierce competition between businesses and communities, decentralize the rich and the poor, increase social injustice.

Zoltan Acs and Nicola Virgill (2010) point out that, for economic sector development, if businesses are effectively regulated, they can play the roles such as: (1) job creation, (2) sustainable region development, (3) GDP and per capita income increase, (4) life quality improvement, (4) import and export balance growth and (5) community development. Therefore, for a low-income economic region, priority should be given to the development of new businesses that are capable of creating jobs and contributing to the improvement of important key goals such as GDP, exports, living standards, skill and community development.

Studying the role of residents in economic development, Lynn Richards \& Matthew Dalbey (2009) show that people are relevant stakeholders that play an important role in the success or failure of policies aiming for society balance. In many policies towards social development, only a small part of the community is involved in decision making and participation because of socio-economic, linguistic and educational barriers. Therefore, to better engage with all citizens, local governments and the development community can be creative in identifying and using new methodologies to attract, respond and share information. Approaching and working with residents in the community effectively and extentionally will help communities realize their vision, self-discipline to create social and economic value and meet the policies' goals. 


\section{The role of the state}

Nam Tra My is one of the mountainous districts in the central coast region that has the highest poverty rate in the country. The government has issued many mechanisms and policies to promote the advantages of each socio-economic development area, of which preserving and developing Ngoc Linh ginseng is one of the priorities for Nam Tra My district. In particular, the legal articles directly related to mechanisms, legal corridors and policies to preserve and develop Ngoc Linh ginseng are: Resolution No.30a/2008/NQ-CP 27 Dec 2008 for rapid and sustainable poverty reduction program in 61 poor districts (including Nam Tra My district); Decision No.1976/QD-TTg 30 Oct 2013 of the Prime Minister approving the master plan on development of medicinal herbs up to 2020 and orientations to 2030, including the planning for development of Ngoc Linh ginseng; Decree 210/2013/ND-CP 19 Dec 2013 on policies to encourage enterprises to invest in agriculture and rural areas. On 11 Sep 2015, the government issued Document No.7168/VPVP-KGVX on unifying scheme for conservation and development of Ngoc Linh ginseng until 2030. After obtaining the approval from government, there is an tremendous increase in Ngoc Linh ginseng conservation and development; which different branches and levels from the central to local participated in crucially, bringing many important results.

In the face of the precious ginseng varieties extinction, the government decided to establish a national restricted zone in areas with concentrated ginseng in Kon Tum and Quang Nam provinces. Ngoc Linh ginseng has been put on the list of plants banned from exploitation and illegally traded. Although this ginseng has escaped extinction but its safety is still low at threat level E in Vietnam Red Book. The government and the Ministry of Health are gradually studying solutions to invest in sustainable development for the pharmaceutical and export industries by making Ngoc Linh ginseng a major crop in the uplands, taking advantage of the climate, soil. Their purpose is to grow ginseng to produce goods and create material areas, aiming to affirm a brand of "Vietnamese ginseng" just like "North Korean ginseng", "Chinese ginseng", "Japanese ginseng", "American ginseng". Along with the direction to expand the area of ginseng cultivation, young ginseng trees, under 6 years old, is strictly prohibited from exploitation. Scientists also conducted research exploration in other mountainous regions with high climate, equivalent in central Vietnam, to define and expand the growing region of ginseng.

In addition, Ngoc Linh ginseng is recognized as a medicinal material with high economic value, being capable of solving employment problems, improving the lives of people in highland areas of Quang Nam and Kon Tum provinces, including Nam Tra My district. The state has implemented many activities in protecting and developing Ngoc Linh ginseng brand such as building scientific and practical basis for geographical indications and promote the brand to domestic and foreign markets. The project "Building a geographical indication "Ngoc Linh" for ginseng root products" is a practical step, showing efforts to protect and develop the brand. On that basis, the National Office of Intellectual Property of Vietnam has issued a certificate of registration for geographical indications Ngoc Linh (Decision No.3235/QD-SHTT 16 Aug 2016). Geographical indication Ngoc Linh ginseng became the $49^{\text {th }}$ that Vietnam has protected and the $45^{\text {th }}$ geographical indication of Vietnam. The publication of the geographical indication Ngoc Linh ginseng is a valuable commercial property, contributing significantly to the socio-economic development of the province and nation. Therefore, the good protection of intellectual property rights will bring high economic efficiency, duration, sustainability and protect the rights and legitimate interests of producers and consumers. .

Especially on 5 Jun 2017, the Prime Minister signed Decision 787/QD-TTg on unifying the addition of Ngoc Linh ginseng into the national product list from 2015 - 2020. This is a drastic action from the government to emphasize the role of Ngoc Linh ginseng in socio- 
economic development of Quang Nam and Kon Tum provinces, especially in improving livelihoods and life quality among ethnic minorities in Nam Tra My district (Quang Nam) and Tu Mo Rong district (Kon Tum). At the "Ngoc Linh Ginseng" Conference in Kon Tum province on 6 Sep 2019, the Prime Minister affirmed that Ngoc Linh ginseng is "the national treasure of Vietnam" and is one of the most important products. In terms of medicinal materials and national treasures, it is necessary to link closely with the national policies and people's livelihood. Being included in the national product list has opened up many opportunities for Ngoc Linh ginseng and helped it grow to the new heights. Therefore, it is expected that ministries and central branches will have to actively work with localities to develop larger programs, plans and projects to continue raising economic value of this product and bring it to the international market.

To support the preservation and development of Ngoc Linh ginseng, the Ministry of Science and Technology issued Decision No.3750/QD-BKHCN 28 Dec 2017, approving the Scheme on product development framework for Vietnam National Ginseng (Ngoc Linh). In addition, the Ministry has also allocated funds for the locality to implement two topics: "Conservation research and building the original source of Ngoc Linh ginseng (Panax vietnamensis Ha et Grushv) in Nam Tra My district, Quang Nam province" and "Internet of Things (IoT) research and application to manage the original and conservation area in Nam Tra My district, Quang Nam Province". In addition, the Ministry has also developed a program to coordinate activities with the People's Committee of Quang Nam province in the orientation of development and conservation of Ngoc Linh ginseng period $2018-2025$.

In order to promote Ngoc Linh ginseng as a product and brand, the Ministry of Culture, Sports and Tourism has allowed the People's Committee of Quang Nam province to organize the Ngoc Linh ginseng festival in August every year and a ginseng fair from $1^{\text {st }}$ $3^{\text {rd }}$ monthly. Ngoc Linh ginseng Festival has been successfully held for three consecutive years from 2017 to 2019 . Its fairs are held from $1^{\text {st }}$ to $3^{\text {rd }}$ every month at the Center for cultural, physical training and sports of Nam Tra My district. The events have attracted lots of customers and did not meet demand. Over the days of the fair, over 1,000 visitors came to visit and shop, with monthly revenue ranging from VND 2 to 10 billion (People's Committee of Nam Tra My District, 2019).

Regarding the government's investment in the implementation of Ngoc Linh ginseng conservation and development project in Nam Tra My district, the state has supported the construction of material bases for breeding farms with VND 3.5 billion; investment in buying seeds with VND 3.5 billion; scientific research to conserve and develop Ngoc Linh ginseng with VND 15 billion, of which the total investment capital for infrastructure of the ginseng area to 2020 has been approved VND 370 billion (People's Committee of Nam Tra My District, 2017b ).

After 4 years since the implementation of the project on the conservation and development (from 2016 to 2019) in Nam Tra My district, there have been many positive changes:

Economic: (1) Developing ginseng plants in 7/10 communes in the Ngoc Linh ginseng conservation and development planning of Quang Nam province, initially giving very positive results, the percentage of plants surviving is $70 \%$ (2) Developing a plan to provide forest environment to grow Ngoc Linh ginseng for people in Nam Tra My district with a total area of up to $1,133.28$ ha (3) Preserving 100 ha of Ngoc Linh ginseng, equivalent to 2 million plants and develop a 400-ha ginseng material area equivalent to 20 million ginseng plants in Quang Nam province. Manufacturing and processing a number of products from Ngoc Linh ginseng to meet the needs of domestic and foreign markets, increasing export turnover for the country (4) Improving productivity and quality of Ngoc Linh ginseng with effective production to meet the needs of protection, conservation of genetic resources and 
raw materials supply for the processing industry of Ngoc Linh ginseng.

Social: (1) Through the conservation and development of Ngoc Linh ginseng, 500 1,000 jobs are created annually for local laborers, contributing to hunger eradication and poverty alleviation for about 3,150/4,744 poor households; additional 100-200 ha ginseng is preserved and developed; 4,000 ha of forest is protected and grown (30,000 ha expected to plant) (2) Maintaining a stable area of natural forest, attracting animals and plants, conserving bio-diversity in Ngoc Linh Nature Reserve, preventing erosion, protecting watershed forests and ecological environment in the region, creating favorable conditions for people to develop local socio-economic development (3) The infrastructure of the ginseng development area has been gradually renovated, creating favorable conditions for goods exchange between the mountains and the peninsulas, stimulating people to invest in development with fast and sustainable poverty reduction (4) Ecotourism began to be formed and developed, especially tourism in the region of growing ginseng, gradually creating Ngoc Linh ginseng tourism brand, attracting domestic and foreign tourists.

Ngoc Linh ginseng products have been paid special attention and by the state and ministries of Vietnam. The state, related ministries and agencies have implemented many projects and programs to support and attract investment as well as register trademarks and geographical indications to build Ngoc Linh ginseng into a product nationally, helping socio-economic development, creating jobs and improving the livelihoods of people in the highland areas of Nam Tra My district in particular and the two provinces Quang Nam and Kon Tum in general.

\section{The role of local government}

To develop Ngoc Linh ginseng, Quang Nam province has issued many legal documents to encourage its conservation and development, such as (1) Resolution No.114/2014/NQHDND 11 Jul 2014 from People's Council on the mechanism of encouraging, preserving and developing Ngoc Linh ginseng in Quang Nam province 20142020; (2) Resolution No.168/2015/NQ-HDND 7 Jul 2015 from People's Council on leasing forest environment for growing Ngoc Linh ginseng in Quang Nam province; (3) Decision No.34/2015/QD-UBND 26 Nov 2015 from People's Committee on forest environment lease for growing Ngoc Linh ginseng in Quang Nam province; (4) Resolution No.05NQ/TU 17 Aug 2016 From Quang Nam Provincial Party Committee on socio-economic development in mountainous areas associated with the orientation of implementing a number of major projects in the Western region of Quang Nam province 2016 - 2020, orientation to 2025; launching a project group to protect, develop and improve forest efficiency, product exploitation under the forest canopy, emphasizing the development of Ngoc Linh ginseng; (5) Decision No.395/QD-UBND 27 Jan 2016 on planning approval of preserving and developing Ngoc Linh ginseng in Nam Tra My district, Quang Nam province in the 2016-2020 period and orientations to 2030; planning on 15,000 ha of Ngoc Linh ginseng growing area; (6) Decision No.300/QD-UBND 22 Jan 2018 from People's Committee on the implementation of Resolution No.41/NQ HDND dated 7 Dec 2017 from Provincial People's Council on incentive and conservation mechanisms to develop Ngoc Linh ginseng 2018 - 2025. In addition, Department of Agriculture and Rural Development of Quang Nam province issued Decision No.333/QD-SNN \& PTNT on 29 Jun 2016 on temporary guide to select economic organizations that rent forest environment to grow Ngoc Linh ginseng and medicinal plants.

Quang Nam Department of Science and Technology has also advised the Provincial People's Committee to implement some contents and tasks related to the conservation and development of Ngoc Linh ginseng, such as: (1) researching farming methods and managing reasonable epidemic damage; (2) researching and applying scientific and 
technological advances in propagation to improve the rate and quality of Ngoc Linh ginseng seedlings in Nam Tra My district, Quang Nam province.

Since 2004, Quang Nam has set up a VND 2-billion project to support and develop ginseng areas in Ngoc Linh mountain. By 2019, in addition to the area of 66 ha of ginseng in Nam Tra My district, People's Committee of Quang Nam province and People's Committee of Nam Tra My district have built and operated two medicinal farms located in the core area of Ngoc Linh mountain. The area serves as re-organizing planting areas towards semi-wild ginseng under natural forest canopies on suitable soil and climatic conditions, conserving and developing medicinal plants and ensuring seed sources for pharmaceutical production. It also supports people in seven communes planned in the Ngoc Linh ginseng growing area in Nam Tra My district such as Tra Tap, Tra Don, Tra Nam, Tra Linh, Tra Cang, Tra Don and Tra Leng: (1) Tra Linh medicinal farm is managed by Department of Agriculture and Rural Development of Quang Nam province, with over 7 ha of ginseng planting area, with different ages, but mainly for seed production; annually produce from 100 to 150 thousand trees; (2) Tak Ngo ginseng farm, village 2, Tra Linh commune, managed by People's Committee of Nam Tra My district, with an area of 3 ha; is planning to be expanded to 70 ha in the coming time with the goal of preserving and producing quality seedlings for people and businesses to invest and develop. Currently, 510 thousand seedlings are produced each year from this farm. In addition, the two provinces of Quang Nam and Kon Tum have embarked on researching, testing and applying a number of breeding techniques to protect and develop Ngoc Linh ginseng source.

The construction of a medicinal station and raw material development project in Nam Tra My district has shown positive impacts on people: (1) Creating favorable conditions for households to invest in developing Ngoc Linh ginseng while household capital is not available; (2) Shifting from subsistence and self-sufficient production to the application of advanced techniques, intensive farming to increase productivity, moving toward production based on goods; (3) Enforcing care and protection closely to community groups; (4) Meeting the needs of changing crop structure suitable to ecological conditions to bring economic efficiency; (5) Making people aware of sustainable development, paying due attention to environmental protection, not just depleting natural resources.

In addition, the local government of Nam Tra My district also has many policies to support people in seven communes located in the area of planning for conservation and development of Ngoc Linh ginseng: (1) Land support: households are contracted, managed and protected forests in ecological restoration zones, administrative services and sub-zones protection according to the plan of forest management and protection combined with growing ginseng under the forest canopy; (2) Seed support: the provincial budget supports $80 \%$ of the price for buying ginseng seedlings (the price of ginseng varieties is determined by the Department of Finance each year), but not more than 300 plants/household/year; (3) Credit support: the provincial budget supports the difference between the lending interest rates for poor and near-poor households and the interest rates set by the state bank for commercial banks, the maximum loan amount does not exceed VND 50 million/household, which is used to purchase equipment for management and protection of the ginseng garden, with a loan term not exceeding 7 years (Nam Tra My District People's Committee, 2017a). Credit institutions in the district have focused capital for households in need of loans to grow Ngoc Linh ginseng, lending up to VND 50 billion; (4) Other support: entitle households (who have registered as a group of households) to forest management and funds protection according to current regulations; provide technical guidance and create favorable conditions in the state management of seeds to organize the seed production for investment in developing ginseng raw material areas on assigned land; provide vocational training courses for rural workers under the Prime Minister's Decision No.1956/QD-TTg 27 Nov 2009; supply with training and support for modeling under agricultural extension programs. 
Regarding infrastructure serving the conservation and development of Ngoc Linh ginseng, People's Committee of Nam Tra My district has also actively invested in the construction of road infrastructure, power, water and communication systems and other auxiliary works. The local government also promotes businesses to participate in developing, planting Ngoc Linh ginseng, invests in building production, processing and offproduct facilities. Besides, the provinces also improves the quality of operation, infrastructure of Ngoc Linh ginseng product introduction center (currently using the district's cultural and physical training center to organize). After the project of Ngoc Linh ginseng was approved, traffic to the ginseng region was invested, creating favorable conditions for the travel of people in the mountainous areas. The goods produced are circulated more easily and conveniently, making people support the decision. Currently the roads have been deployed, completed and put into use by the end of 2019 .

In terms of information, propaganda and product promotion, People's Committee of Nam Tra My district has used various, extensive forms on the mass media such as newspapers, television, SMS, social networks on Facebook, trailers on YouTube, on fixed buses, marketplace log on the district portal, broadcast on VTV1 and QRT, broadcast live via YouTube and Facebook system made by District Radio and Television Station, etc. For the people of the district, the form of propaganda by portable speaker, integrated in village and commune meetings; invitations issue to the village are all applied.

In order to ensure the quality of ginseng, People's Committee of Nam Tra My district has established a organizing committee for Ngoc Linh ginseng fair every month from $1^{\text {st }}$ $3^{\text {rd }}$, along with the organizers and appraisal team of the product. The whole group have been always on duty and inspection of products on sale in the market to ensure the quality for customers. The first ginseng market in December 2017 has sold nearly $30 \mathrm{~kg}$ of ginseng, earned nearly VND 2.7 billion and after 3 markets session, the revenue was over VND 10 billion. The most recent session was held from 1-3 Mar 2020 has brought about VND 5.7 billion in revenue, of which Ngoc Linh root ginseng sold about $60 \mathrm{~kg}$, earning nearly VND 4.2 billion (People's Committee of Nam Tra My District, 2020b).

Table 1. Summary monthly market session on Ngoc Linh ginseng at Nam Tra My district (Source: Summary on report of monthly Ngoc Linh ginseng fair organization, People's Committee of Nam Tra My district).

\begin{tabular}{|c|c|c|c|c|c|c|}
\hline \multicolumn{2}{|c|}{ Time } & Visitors & $\begin{array}{c}\text { Number } \\
\text { of Shops }\end{array}$ & $\begin{array}{c}\text { Number of } \\
\text { enterprises }\end{array}$ & $\begin{array}{c}\text { Sold amount } \\
(\mathbf{k g})\end{array}$ & $\begin{array}{c}\text { Revenue } \\
\text { (million VND) }\end{array}$ \\
\hline \multirow{6}{*}{2018} & Jun & 2,000 & 16 & 10 & 65 & 4,700 \\
\cline { 2 - 7 } & Jul & 2,000 & 16 & 10 & 50 & 4,500 \\
\cline { 2 - 7 } & Aug & 2,500 & 25 & 10 & 86.5 & 8,250 \\
\cline { 2 - 7 } & Sep & 1,500 & 16 & 10 & 52.5 & 4,150 \\
\cline { 2 - 7 } & Oct & 1,200 & 16 & 10 & 57 & 4,260 \\
\cline { 2 - 7 } & Nov & 1,100 & 14 & 10 & 67.5 & 5,360 \\
\cline { 2 - 7 } & Dec & 1,000 & 14 & 9 & 51 & 4,100 \\
\hline \multirow{6}{*}{} & Jan & 950 & 13 & 9 & 45 & 3,900 \\
\cline { 2 - 7 } & Feb & 970 & 13 & 10 & 57.5 & 5,100 \\
\cline { 2 - 7 } & Mar & 900 & 12 & 7 & 27 & 2,600 \\
\cline { 2 - 7 } & Apr & 1,000 & 12 & 10 & 58 & 4,200 \\
\cline { 2 - 7 } & May & 1,000 & 12 & 10 & 55 & 4,000 \\
\cline { 2 - 7 } & Jun & 1,100 & 12 & 10 & 60 & 4,200 \\
\cline { 2 - 7 } & Jul & 1,800 & 22 & 10 & 70.5 & 7,550 \\
\cline { 2 - 7 } & Aug & 2,500 & 45 & 10 & 110 & 10,500 \\
\cline { 2 - 7 } & Sep & 2,000 & 37 & 9 & 92 & 8,600 \\
\cline { 2 - 7 } & Oct & 1,400 & 22 & 8 & 55 & 4,700 \\
\cline { 2 - 7 } & Nov & 1,300 & 20 & 6 & 40 & 5,700 \\
\cline { 2 - 7 } & Dec & 1,500 & 20 & 6 & 70 & \\
\hline
\end{tabular}




\begin{tabular}{|c|c|c|c|c|c|c|}
\hline \multirow{2}{*}{2020} & Jan & 1,200 & 20 & 6 & 45 & 4,000 \\
\cline { 2 - 7 } & Feb & 1,300 & 15 & 8 & 30 & 2,700 \\
\cline { 2 - 7 } & Mar & 1,000 & 20 & 8 & 65 & 5,700 \\
\hline
\end{tabular}

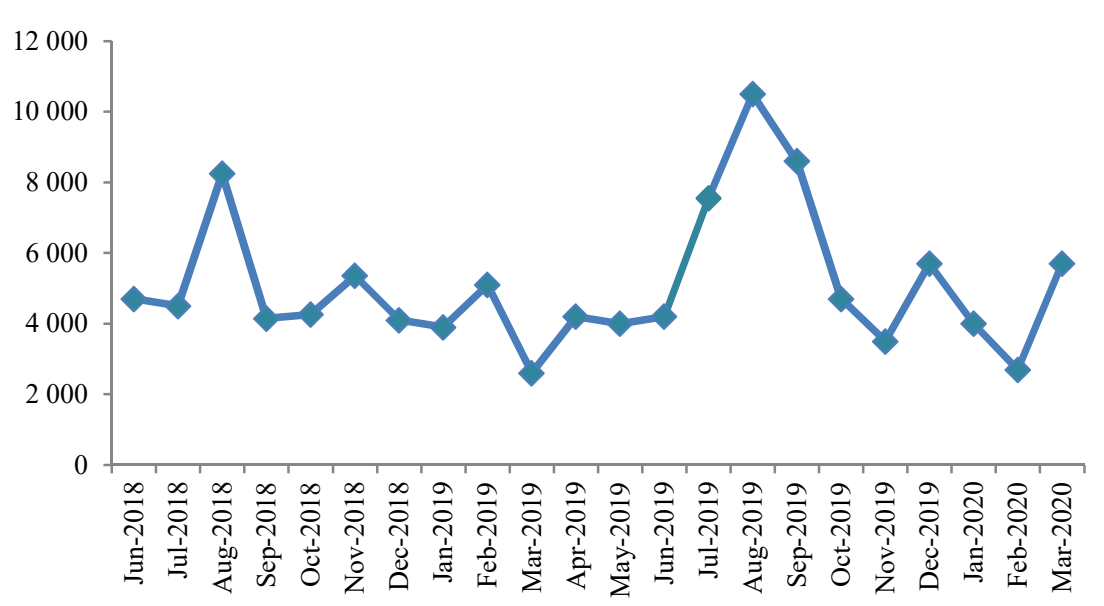

Fig. 1. Revenue on monthly Ngoc Linh ginseng fair Jun 2018 - Mar 2020 (unit: Million VND) (Source: Summary on report of monthly Ngoc Linh ginseng fair organization, People's Committee of Nam Tra My district).

According to the data in Table 1, monthly Ngoc Linh ginseng fair organized by Nam Tra My district has a relatively high and stable revenue from VND 2.6 to 10 billion/fair for the corresponding output from 27 to $110 \mathrm{~kg}$. On the other hand, with the time only taking place within 3 days (from $1^{\text {st }}-3^{\text {rd }}$ monthly), the purchasing power is very high and stable. Especially in August every year since 2017, the period when People's Committee of Quang Nam province organized the ginseng festival, the quantity and revenue from this product has increased sharply compared to other months of the year. The fluctuation of total revenue shown in Figure 1 shows that over the years, the amplitude of fluctuations in total revenue is increasing, the monthly value has reached higher milestones compared to previous year, proving the value of Ngoc Linh ginseng is enhanced critically.

Currently, due to the impact of the global epidemic situation of SARS-CoV-2 and the social isolation order of the government, Nam Tra My district has strictly implemented the instructions in prevention of SARS-CoV-2 in the organization of monthly ginseng fair. Accordingly, People's Committee has changed the form of organizing the fair in April 2020 from traditional sales to online selling via facebook applications at the address: "Ngoc Linh ginseng center" and YouTube channel: "Ngoc Linh ginseng market". The fair time is still from 1-3 Apr 2020. During this time, local people will not stay outdoors but only sell products online via the Internet to ensure the sales are still taking place, the mountainous people can still circulate goods, stabilizing the livelihood against the epidemic situation.

In the coming time, Quang Nam province is promoting supplementary tourism planning for Ngoc Linh ginseng region, Ngoc Linh mountain peak, ginseng culture to focus on other ginseng business services. Ginseng markets have confirmed the position and brand of Ngoc Linh ginseng; creating a stable trading environment with opportunities for investment cooperation, joint venture to produce and consume ginseng. Thereby, people, craft villages, businesses have chances to introduce, promote products, exchange in business and production, bringing Ngoc Linh ginseng to match with rare and precious herbs in the world. 


\section{The role of the enterprise}

In the past, when there was no planning, Ngoc Linh ginseng was grown by people and no businesses participated in the investment. Now it has attracted the attention and investment of the businesses. Currently, 6 enterprises have registered to invest in Ngoc Linh ginseng planting, of which 2 enterprises have organized planting after being approved by the provincial People's Committee to lease forest environment services to grow Ngoc Linh ginseng, the rest are implementing the establishment of records, the total capital of these 2 businesses is about VND 200 billion. In addition, there are 32 enterprises planning to invest in growing ginseng, but People's Committee of Quang Nam province only allows 6 enterprises to experimentally grow. The total area of enterprises that came to contact for survey and registration was 3,125 ha. In addition to the aforementioned businesses, the district also has individuals and collectives that borrow money from banks to invest in growing ginseng. Especially now, there are a number of businesses wishing to invest in building factories processing products from Ngoc Linh ginseng.

The participation of businesses has facilitated the planting movement, through land rental, worker hiring and ginseng products trading from the people. In 2014, the number of households planting ginseng in Tra Linh commune - the original place of finding the longstanding origin of Ngoc Linh ginseng was only about 110 households, it has grown in 7/10 communes to over 900 households, registered on 1,200 ha of ginseng forest environmental services. Ngoc Linh ginseng in Nam Tra My is preserved and developed by a number of certain methods. Specifically, in three communes of Tra Nam, Tra Linh and Tra Cang, Nam Tra My district, people formed 27 groups of ginseng growers with more than 653,500 ginseng plants of various ages.

Currently, there are a number of enterprises involved in the production and processing of Ngoc Linh ginseng of Nam Tra My district such as Quang Nam Ginseng Pharmaceutical Trading Joint Stock Company (Quasapharco), Sam Sam, Paper Material Company in central region, Hoa Thien Phu Group, etc. In addition, there are other enterprises producing and processing Ngoc Linh ginseng in Kon Tum province. Beside trading ginseng root products, these businesses have researched, extracted essence and processed Ngoc Linh ginseng root products into lower-cost, easier-to-consume products for the commercial market: energy drink, health food (Saphraton), K5 ginseng wine, Ngoc Linh ginseng drink, Ngoc Linh ginseng sachet, Ngoc Linh ginseng oolong tea, Ngoc Linh ginseng tea bag, Ngoc Linh ginseng capsules, K5 ginseng tea. The initiative of businesses in researching and developing products of Ngoc Linh ginseng has helped to enhance the value of ginseng species, taking advantage of all parts of the ginseng tree for products suitable with tastes of consumers from ginseng root, ginseng to ginseng tea, Ngoc Linh ginseng drinking water, etc.

Previously, only very high-income people could buy ginseng root to use Ngoc Linh ginseng; however, through products made from the essence of Ngoc Linh ginseng, businesses have approached to more consumers with affordable price and convenient method. According to the forecast, along with the development of Ngoc Linh ginseng from businesses and local people, the annual output of ginseng may reach 7 to 10 tons, equivalent to a value of VND 420 - 600 billion/year. After 2020, the output is expected to reach about 30 tons with many high-quality product lines such as cosmetics, functional foods (Local Department, Central Economic Board, 2017).

To attract investment from foreign businesses, Nam Tra My District has visited, exchanged, learned experiences and cooperated with Ham Yang District (South Korea) where Korean ginseng is planting and developed effectively. The district is also promoting with Canada, the United States and Russia, which have valuable ginseng in the world to hopefully facilitate cooperation and attract businesses to invest in ginseng, bringing the 
brand of two Ngoc Linh ginseng types to international market.

\section{The role of the people}

Before there was any project to preserve and develop Ngoc Linh ginseng until 2030, its price is low. However, as the project was approved by the government, with the coordination and support of media agencies, Ngoc Linh ginseng is introduced and promoted the true values to all classes of people inside and outside the province, making the price increase. Every hectare of ginseng cultivation after 5 years can generate VND 30 to 50 billion. This has made ginseng planting become strong, in addition to the existing family capital, many households have actively participated in taking loans to invest in growing ginseng. In 2015-2016, the credit lent from financial institutions to people to grow ginseng was up to nearly VND 50 billion. In 2014, the number of households growing ginseng in 1 commune of Tra Linh was only 110 with registering 66 ha. By the end of 2019, seven communes has grown to over 900 households with over 1200 ha. The growth rate in ginseng planting is nearly $900 \%$ and it continue to increase strongly. The district has planned and localized nearly 7,000 ha to the service environment for growing ginseng.

In the past, people in Nam Tra My district only applied traditional methods and practices by using a wide hole to pick and put the plants in any place that is safe, making the yield become low and prolong harvest time. However, since the government has paid attention, especially after Ngoc Linh Ginseng Conservation and Development Project was approved, Department of Agriculture and Rural Development of Quang Nam has studied and promulgated the process of planting, tending and protecting Ngoc Linh ginseng; Quang Nam Department of Science and Technology has collaborated with localities to study the process of growing Ngoc Linh ginseng by using micro-fertilizer, guiding people to use probiotics to compost forest vegetation to fertilize ginseng. Since people have applied to production, it has brought positive results by shortening the harvest time to 1-2 years with large and beautiful tubes.

Through propaganda, mobilization and participation in the project of planting Ngoc Linh ginseng, Cadong, Xe Dang, Bh'nong and Kinh people's awareness of forest protection has been dramatically changed. Local people know how to keep forests to grow Ngoc Linh ginseng, each household knows how to keep, protect and take advantage of the area under old forest canopy. Therefore, the old forest system of Ngoc Linh mountain has until now been well preserved from the awareness of upland people, without indiscriminate deforestation, slash and burn cultivation as other places.

In addition, through propaganda and mobilization, people in Nam Tra My district have also actively learned by themselves, following the instructions of local officials, accessing loans to support to receive seeds from Dak Ngo medicinal station of Nam Tra My and Tra Linh districts of Quang Nam province on growing and replicating Ngoc Linh ginseng. In general, since the project was approved in combination with the widespread communication, the value of Ngoc Linh ginseng has been raised to create a stable life for people in the region, many households rose from the poor to the better off, the rich, making the mountainous countryside flourish.

\section{Conclusion}

In the orientation and goals of socio-economic development of the country, the role of all levels from the state to localities, from businesses to people are very important. The harmonious coordination and promotion of the rights and obligations of each subject will help the socio-economic development policies be applied to the maximum and effectively 
promote the efficiency such policies bring.

Research shows that selecting and planning the right policies to conserve and develop an endemic, high-value product can help a locality to reduce poverty and develop sustainably, improving living standard and social security like how Ngoc Linh ginseng has performed in Nam Tra My district. The success of the model stems from the right guidelines from the state and local governments have discovered the importance to devise policies to conserve genetic resources, build and develop trademarks. Moreover, investment in scientific research, infrastructure and conservation areas have been accelerated to create commercial products besides conservation. The most important outcome is the way of delivering products and conservation models associated with economic development from Ngoc Linh ginseng to indigenous people themselves, helping them realize the value from local tree species. Since then, the local government has created appropriate mechanisms and policies on land, credit and seedling support in line with the commitment so that people have motivation to focus on economic development, eradicate abolishing deforestation, slash and burn practices. In addition, allowing businesses to invest in developing the model of Ngoc Linh ginseng also has a selectivity to ensure the operation of the business within the conservation framework. Enterprises are responsible for creating added value, producing post-processed products and perfecting the supply chain of products in the market, ensuring that people still directly benefit from policies. People play the role of directly holding, protecting the forest and participating in direct production, economic development, poverty alleviation from Ngoc Linh ginseng. The preservation, protection of forests, economic development from forests come directly from the consciousness of the people, which is the success of a policy. This has been brought about by Ngoc Linh ginseng to Nam Tra My district, Quang Nam.

The success of Ngoc Linh ginseng development to become a species bearing the trademark of "National treasure of Vietnam" and "key tree of poverty reduction" for households in upland areas within 4 years, is an experience worth learning and needs to be replicated in the mountainous areas of Vietnam as well as other countries in Southeast Asia.

\section{References}

1. A. Dhaliwal, International Journal of scientific research and management (IJSRM) 4(6), 4262-4269 (2016). DOI:10,18535/ijsrm/v4i6.08

2. T.F.-L. Yu, International Journal of Social Economics 27(8,9,10), 994-1013 (2000) DOI: $10.1108 / 03068290010337279$

3. J. Doran, I. McCarthy, Journal Cogent Economics \& Finance Mar (2018) DOI: 10.1080/23322039.2018.1442093

4. K.T. Liou, International Journal of Public Administration Jun, 1257-1283 (2007) DOI: 10.1080/01900699808525347

5. L. Richards, M. Dalbey, Journal Community Development 37(4), 18-32 (2009) DOI: 10.1080/15575330609490193

6. M. Kubickova, Czech Journal of Tourism 5(2), 73-92 (2016) DOI: 10.1515/cjot-20160005

7. V.T. Nguyen, T.P. Nguyen, Hue University Journal of Science 118(4) (2016)

8. Institute of Medicinal Materials, Journal of Medicinal Materials 16(3) (2011)

9. Z. Acs, N. Virgill, Foundations and Trends in Entrepreneurship 6(1), 1-68 (2010) DOI: $10.1561 / 0300000031$ 